\title{
Determinants of Union Participation of Public Sector Organizations in Sri Lanka
}

\author{
Prasadini N. Gamage \\ Senior Lecturer \\ University of Kelaniya \\ E-mail: prasadinigamage@yahoo.com \\ And \\ Gayani V. Hewagama \\ Senior Lecturer \\ University of Kelaniya \\ E-mail: ghewagama@gmail.com
}

\begin{abstract}
This study explores the relationship between various predictors of union participation namely; union loyalty, union instrumentality, them and us attitude and workplace collectivism on employees' willingness to participate in union activities of public sector organizations in Sri Lanka. A structured questionnaire was distributed among randomly selected sample of 254 unionized employees in seven large scale highly unionized public sector organizations. The statistical results of the study revealed that member attitudes namely; union loyalty and union instrumentality were positively associated with union participation. However, union loyalty was the significant and most powerful predictor of union participation.
\end{abstract}

Key Words: Union Participation, Union Loyalty, Union Instrumentality, Them and Us attitude, Workplace Collectivism

\section{History of the Trade Unions in Sri Lanka}

Trade unions are democratic organizations that would assist the social and economic aspirations of workers. The inception of trade unions in Sri Lanka dates back to the period of late 1800's. It has been generally said that the first person to introduce the idea of trade unions in Sri Lanka was A. E. Bultigens. While studying at Cambridge University, he has been inspired by the work of Fabian Society and the Social Democratic Federation and on the return to Ceylon wrote an article to a monthly journal so called "Independent Catholic" in 1893. In his article he emphasized the importance of establishing trade unions to protect the rights of the workers and especially appealed to the workers engaged in printing industry whose wages were very low and working conditions were very poor. In another three months later, fifty employees of British owned H.W. Cave Company, the largest firm of printers and book sellers in Colombo, stuck work on the ground of delay in the payment of wages to the workers. On the $17^{\text {th }}$ of September 1893, the strikers held a meeting and formed the "Ceylon Printers Society" the first trade union not only in Sri Lanka but also in South Asia. In the year following the printers agitation was formed, strikes became a common feature of urban working class and some middle class thought; especially due to lack of education those workers required strong leaders. The interconnections between political, religious revival and labour unrest became more explicit 
between in 1906 and 1915. The strike of carters in 1906 was the first occasion when resistance to authority by significant section of the working class met with success. During that period trade union movement was leaded by educated people from urban working class. Mr. A E Gunasinghe was one of the most prominent leaders among them. All Ceylon Trade Union Congress was formed in 1928 and in 1933 the leadership of trade union movement was taken charge of by young leaders with Marxist tendencies, who had been educated abroad. With regard to trade union movement in Sri Lanka, the practices established by the Marxists were generally followed by the other parties which became involved in trade unionism subsequently. Today it is possible to see that there are number of trade unions established to represent various political parties of the country in most of the organizations.

The Trade Unions Ordinance No 14 of 1935 was established in 1935 in order to regulate formation and getting membership of trade unions. It defines a trade union as a combination of workmen or employers temporally or permanently with its objects being one of or more of the following; the regulation of their relationships or their representation in trade disputes or imposing of restrictions on the conduct of any trade or business, organizing or financing of strikes and lock outs in any trade or industry or the provision of pay or other benefits.

\section{Problem Statement}

According to Amarasinge (2011) trade union recognition should be compulsory where a union had 51\% membership and discrimination against union activists and members should be prohibited. Further he states that the public sector unions, which do not have collective bargaining as such, but have "collective disputes" with their employer the State. From the union's side it is very important to retain their members in order to become stronger specially for the purpose of bargaining. However, in Sri Lanka like in most of the developed and developing countries both the registration and getting membership of trade unions are decreasing (Department of Labour, Sri Lanka). If most of the employees are not willing to get the membership of trade unions it is important to find out the reasons for employees to participate in trade unions.

Early research on union participation highlighted the impact of demographic and socialization variables and attitudinal measures on union participation. Though, in recent research attention has been paid to examine the relationship between behavioral attitudes such as union loyalty, union instrumentality, commitment and union participation (Fullagar \& Barling, 1989; Kelloway and Barling, 1993; Terick et al , 2007; Metochi , 2002; Bolton et al , 2007 ). As far as Sri Lankan studies related to union participation are concerned, Jinadasa \& Opatha (1999) empirically studied union participation in five state sector organizations, revealing a strong need of trade unions among employees. However, in Sri Lankan context no empirical study has been conducted to find out the relationship between member attitudes (union loyalty, union instrumentality, them and us attitude and workplace collectivism) and union participation. This is the research gap that has been addressed in this research. Following research questions were addressed in the study:

1. What is the relationship between union members' perceived union loyalty and willingness to participate in union activities? 
2. What is the relationship between union members' perceived union instrumentality and willingness to participate in union activities?

3. What is the relationship between union members' perceived them and us attitude and willingness to participate in trade union activities?

4. What is the relationship between union members' perceived workplace collectivism and willingness to participate in trade union activities?

5. What is the aggregate effect of union loyalty, union instrumentality, them and us attitude and workplace collectivism on union participation?

\section{Objectives of the Study}

The following are the objectives of the study.

1. To identify the relationship between union members perceived union loyalty and willingness to participate union activities.

2. To examine the association between union members perceived union instrumentality and willingness to participate in union activities.

3. To investigate the link between union members perceived them and us attitude and willingness to participate in trade union activities.

4. To examine the association of union members perceived workplace collectivism and willingness to participate in trade union activities.

5. To identify the aggregate effect of all the determinants namely; union loyalty, union instrumentality, them and us attitude and workplace collectivism on union participation

\section{Literature Review}

\section{Union Participation}

Union participation means the collective involvement of members in union related activities which are closely related to the effective functioning of the union (Bolton et al, 2007). Union participation activities could be divided into two main categories namely formal and informal activities. Formal activities consist of involvement in elections, participation of meetings, voting, filing grievances and serving as an officer (Fullagar et al, 1995). Informal activities include helping other members to file grievances, reading union publications, talking about the union with others (Fullagar et al, 1995).

\section{Determinants of Union Participation}

Union participation was measured by using various dimensions. Cohen (1994) empirically identified the similarities and differences among six forms of union participation. ; union commitment, participation in decision making, participation in union activities, attitudinal militancy, serving in elected offices and the propensity to strike. Most of the research on union participation considered it as a multi dimensional construct (McShane, 1986; Cohen, 1994; Fullagar et al 1995; Tetrick et al, 2007; Jinadasa \& Opatha, 1999). Shore and Newton (1995) in their study included measures such as communication and civic virtue.

According to the literature the most important demographic variables that had been studied are gender, age and race (Gorden et al, 1980; Metochi, 2002; Fullagar, 1986; Kuruvilla et al, 1990). However, in recent research attention has been paid to examine the relationship between behavoural attitudes and union participation (Metochi, 2002; Terick et al, 2007; Bolton et al, 
2007). Previous studies on union participation have suggested that having positive attitudes about the union is positively related to voting for unionization (Barling, Kelloway \& Bremermann, 1991; Desphante \& Fiorito, 1989). Fullagar \& Barling (1989) found that union loyalty resulted in greater formal participation in union activities. It implies that, the union members who feel loyalty to their union are more likely to vote in union elections and participate in union meetings and activities etc.

Morrow \& McElroy (2006) found that there is a significant positive relationship between satisfaction with communication from national union leaders and union loyalty. Aryee and Debrah (1997) by obtaining a sample from unionized employees in Singapore studied demographic factors and union participation and the model accounted for $43 \%$ variance in participation. Monnot et al, (2010) found the magnitude of the relationship between commitment and participation was moderated by status -based group members, white collar vs. blue collar.

Shore, Tetrick, Sinclair, and Newton (1994) developed another model on union commitment and participation. According to the model organizational commitment, job satisfaction and pro-union attitudes are the antecedents of union commitment. Further the relationship between union instrumentality and union commitment is mediated by pro-union attitudes. This model was developed based on two views. The first view is aligned with the economic exchange perspective which emphasizes that people are committed to unions due to instrumentality perceptions of the union. This view implies that unions are able to improve the terms and conditions of workers. The second view deals with the social exchange perspective which sees union as a source of support for its members (Shore et al, 1994). By taking five large scale service organizations in Sri Lanka as the sample Jinadasa and Opatha (1999) empirically investigated the impact of personal factors, job factors and perceptual factors on union participation and found age, sex, number of dependents, political activism, job experience, perception about union performance, union leaders, union management relations influence membership participation in trade union activities.

\section{Conceptual Framework}

Based on the literature a model was developed by the researches and it is presented in Figure 1. As demonstrated in the model the union participation is directly influenced by attitudes namely; union loyalty, union instrumentality, "Them and Us" attitude and workplace collectivism.

\section{Figure 1: Conceptual Framework}

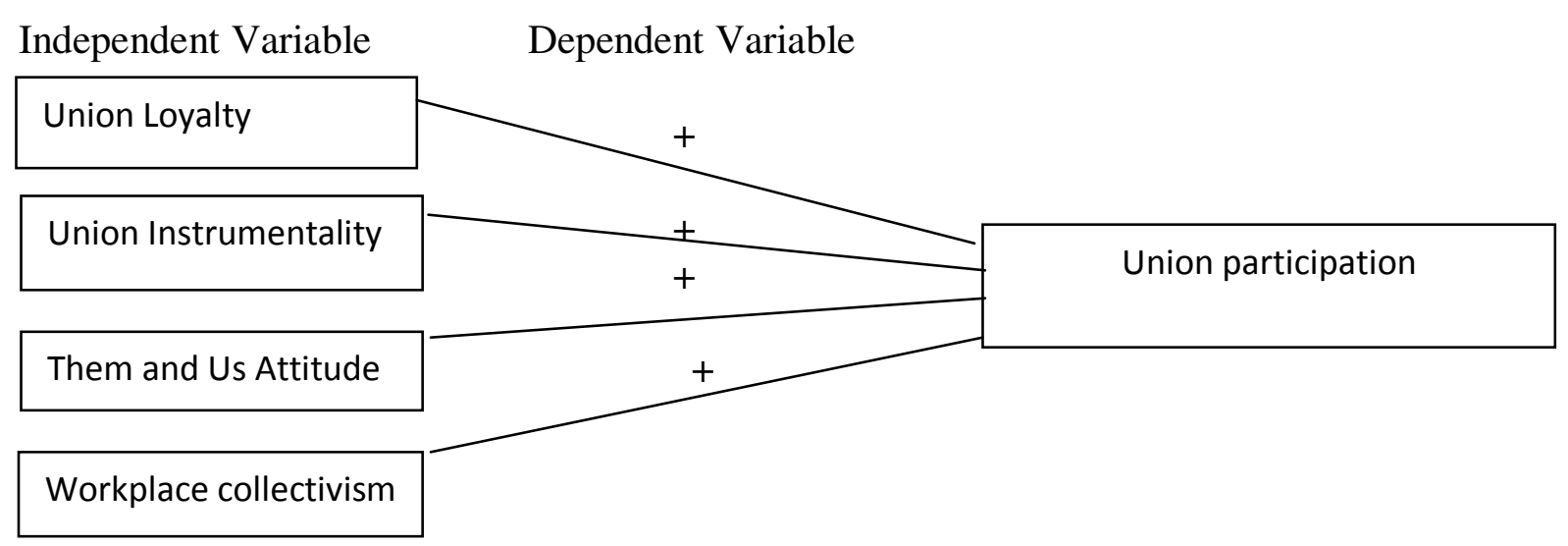

Determinants of Union Participation..... 


\section{Working Definitions of Variables}

According to the conceptual framework shown in Figure 1, the dependent variable is union participation and the independent variables are union loyalty, union instrumentality, them and us attitude and workplace collectivism. Model illustrates that union loyalty, union instrumentality, them and us attitude, and workplace collectivism are positively correlated with members' union participation. Working definitions of the variables under the study are given in Exhibit 1 .

Exhibit 1: Variable Definitions and Sources of Measure

\begin{tabular}{|l|l|}
\hline Variables & Definition and Sources of Measure \\
\hline Union Loyalty & $\begin{array}{l}\text { Degree of pride in union (Gorden et al, 1980). Modification of the scale by } \\
\text { Gorden et al, (1980). }\end{array}$ \\
\hline Instrumentality & $\begin{array}{l}\text { Economic exchange underlies the notion of union instrumentality, which is } \\
\text { defined as a cognitive assessment of the costs and benefits associated with } \\
\text { union membership (Newton \& Shore, 1992). Based on the literature scale } \\
\text { was formulated by the researchers. }\end{array}$ \\
\hline Them and Us & $\begin{array}{l}\text { "Viewing management in a stereotypical fashion can also influence } \\
\text { members' willingness to become involved in the union" (Metochi, 2002, } \\
\text { pp. 90-91). Scale by Metochi, (2002) which was derived mainly from } \\
\text { Jowell et al, 1986 and Kelly and Kelly (1994). }\end{array}$ \\
\hline $\begin{array}{l}\text { Workplace } \\
\text { Collectivism }\end{array}$ & $\begin{array}{l}\text { Collectivism is a 'social pattern . . of closely-linked individuals ... who } \\
\text { are willing to give priority to the goals of the group over their own personal } \\
\text { goals' (Triandis 1995: 2 as in Cregan, Bartram and Stanton, 2009). } \\
\text { Collectivism is expressed in terms of collective attitudes and behavior. To } \\
\text { measure workplace collectivism, Brown et al, (1986) scale was used with } \\
\text { modification. }\end{array}$ \\
\hline $\begin{array}{l}\text { Union } \\
\text { Participation }\end{array}$ & $\begin{array}{l}\text { Union participation refers to involvement in collective action (Metochi, } \\
\text { 2002) and other union related activities that are closely related to the } \\
\text { effective functioning of union (McShane, 1986). Scale was developed with } \\
\text { the use of existing measures of Nicholoson et al, 1981; Shore and Newton } \\
\text { (1995) and Metochi, (2002) as well. }\end{array}$ \\
\hline
\end{tabular}

\section{Statements and Rationales for Hypotheses}

Most of the research considered union loyalty as the predictor of union participation (Gorden et al, 1980; Shore \& Newton, 1995). Gorden et al, (1990) introduced a four dimensional model of union commitment. The four dimensions in this model are (a) union loyalty, (b) responsibility to the union, (c) willingness to work for the union, and (d) belief in unionism. Out of these four dimensions union loyalty is the most prominent variable of union commitment. Motochi (2002) found that union loyalty is the most significant predictor of willingness to participate in trade unions. According to the above mentioned studies, union commitment has a positive significant relationship with union participation. Union loyalty has been accepted as one of the most significant dimensions of union commitment. Subsequently it was hypothesized that: 


\section{H1: There is a positive relationship between perceived union loyalty and union} participation.

Bamberger, Klugar \& Suchard (1999) in their meta-analysis showed that union instrumentality, pro-union attitudes, job satisfaction and organizational commitment were antecedents of union commitment and which in turn contributed to union participation. Hammer, Bayazit and Wazeter (2009) found that union instrumentality was positively related to union loyalty. Moreover, Fullagar and Barling (1989) found that relationship between union loyalty and participation in trade union activities is moderated by union instrumentality. Employees have a positive feeling about trade union acts for the betterment of its members by achieving desired outcomes. Based on the above literature it was hypothesized that:

\section{H2: There is a positive relationship between perceived union instrumentality and union participation.}

According to the past literature on influence of union members' attitudes towards participation in trade union activities, very few studies had been conducted to measure the union members' stereotypical attitudes about the management and these findings were not consistent. Allen and Stephenson (1983) as cited in Metochi, (2002) investigated and found that stronger the group identification then there was a high tendency to view the management in a stereotypical manner. Kelly and Kelly (1994) revealed that group identification, collectivist orientation and stereotypical perception of the out-group were significant determinants of union participation. The argument here is that most of the unionized employees believe that management's daily conduct is injustice since they are willing to participate in trade union activities in order to protect their rights and privileges. Hence it was hypothesized that:

H3: There is a positive relationship between union members perceived them and us attitude and willingness to participate in trade union activities.

Only a handful of empirical studies have used social identity theory to investigate collectivism in union members (e.g. Kelly and Kelly 1994; Metocchi 2002). Social identity theory proposes that people wish to belong to a group that they perceive to be distinct from other groups in order to raise their self-esteem (Cregan et al, 2009). An individual's perception forms the basis of his/her social identity (Tajfel and Turner 1986 as in Cregan et al, 2009). Accordingly, union members' willingness to participate in union activities develops with worker's social identification with the union. Unions who adopt a mobilizing strategy hope to develop these aspects of collectivism in their membership so that in the future, loyal, active members encourage other workers to take part in the struggle (Kelly 1998). A study done by Cregan, Bartram, and Stanton (2009) presents an analysis of the impact of social identification and transformational leadership on aspects of members' collectivism in the form of union loyalty and willingness to work for the union. The findings of this study revealed that social identification and transformational leadership were associated with members' union loyalty and willingness to work for the union, where social identification acted as a mediating variable in both cases. Based on the above literature the following hypothesis was formulated:

H4: There is a positive relationship between workplace collectivism and union participation. 
By considering all the literature above it is important to identify the aggregate effect and significant predictors of the union participation. Hence final hypothesis of the study was:

\section{H5: Union loyalty, union instrumentality, them and us attitude and workplace collectivism have a combined significant effect on union participation.}

\section{Methodology \\ The Sample}

Union membership is much higher in public sector than in private sector and in manufacturing than in service sector (Bender \& Sloane, 1998). The sample consists of seven large scale Public sector companies located in Western Province in Sri Lanka. In Sri Lankan context trade unions exist in every state sector organization and those unions were established based on different political ideologies, category of employment, place of birth, language speaking, ethnic group etc. In this sample at least there are three trade unions representing different political parties and multiplicity of trade unions is very common. In Sri Lanka trade unions are more common in public sector than private sector. The most of the operational employees tend to get unionized than executive level employees do. Hence sample consisted of randomly selected operational level employees. 350 questionnaires were distributed in manual forms in the selected seven companies, 50 questionnaires for each organization. After rejecting the incomplete questionnaires 254 valid questionnaires were used for data analysis purpose. Hence the response rate was 72.5 percent. The responses to the questionnaire were on 5-point Likert scale.

\section{Study Setting}

The study investigated the impact of union member-related variables namely union loyalty, union instrumentality, them and us attitude and workplace collectivism on union participation in operational level employees in public sector organizations. Hence, this study was analytical or hypotheses testing in nature. There was no intention of establishing definite cause effect relationship between the variables. Thus the type of the investigation of this study was correlation rather than causal. Time horizon of the study was cross sectional due to the reason that the data collection was done at a single point of time. The unit of analysis is individual; operational level employee.

\section{Reliability}

Reliability of measure is established by testing both consistency and stability (Sekaran, 2006). The internal item consistency reliability was examined with Cronbach's alpha test. The Cronbach's alpha coefficient was calculated for aggregate sample of 254 respondents. The results revealed that alpha value of each instrument was above .7 suggesting that the internal reliability of the instrument was satisfactory (Table 1).

Table 1: Reliability of the Each Instrument

\begin{tabular}{|l|l|l|}
\hline & Variables & Cronbatch's Alpha \\
\hline 1 & Union Loyalty & 0.855 \\
\hline 2 & Union Instrumentality & 0.750 \\
\hline 3 & Them \& Us & 0.744 \\
\hline 4 & Workplace Collectivism & 0.725 \\
\hline 5 & Union participation & 0.893 \\
\hline
\end{tabular}




\section{Validity}

Validity of the instrument was established by detailed definition or conceptualization and operationalization of the behavioural domain or universe of interest; and indirect way- high internal consistency reliability (Sekeran, 2006). Construct validity of the questionnaire was tested by using factor analysis. One rule of thumb frequently used is that factor loadings of .30 or higher should be considered in the interpretation of a factor. Factor loadings in the range of 0.30 to 0.40 are considered to meet the minimal level for an interpretation of structure and loadings 0.50 or greater are considered practically significant (Hair et al., 1998). In the case of loading exceeding +0.70 it is considered as being indicative of a well-defined structure and is the goal for any factor analysis (Hair et al., 1998). Union Loyalty, Union Instrumentality, Them \& Us, Workplace Collectivism and Union Participation had 32 items and principal component factor analysis produced results of factor loading over 0.5 for each item. The internal consistency of items within each variable was shown by alpha coefficients being greater than 0.60. Cumulative percent of extractions sum of squared loading for Union Loyalty, Union Instrumentality, Them \& Us, Workplace collectivism and Union Participation were 70.07\%, 57.6 \%, 41.8\%, 50.1\% and $75.9 \%$ respectively. These results of factor analysis showed that construct validity of the questionnaire was at satisfactory level.

\section{Data Analysis and Discussion of Results}

There were five hypotheses of the study. the hypotheses from first to four were tested by using statistical techniques of correlation and linear regression analysis. As final hypothesis of the study involved in testing the aggregate effect of all the variables on union participation, multiple regression analysis was used.

Table: 2 Correlation Data among Variables

\begin{tabular}{|c|c|c|c|c|c|c|c|}
\hline \multirow[t]{2}{*}{ Variables } & \multirow[t]{2}{*}{ Mean } & \multirow{2}{*}{$\begin{array}{l}\text { Std. } \\
\text { Deviation }\end{array}$} & & \multicolumn{4}{|c|}{ Correlations } \\
\hline & & & 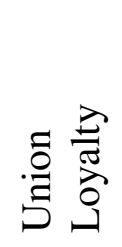 & 总莺 & $\begin{array}{l}\stackrel{\infty}{D} \\
\otimes \\
\tilde{\Xi} \\
\stackrel{\Xi}{F}\end{array}$ & 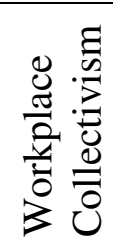 & 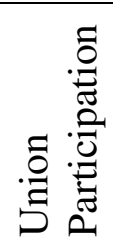 \\
\hline $\begin{array}{l}\text { Union } \\
\text { Loyalty }\end{array}$ & 3.09 & .970 & 1.0 & $.550^{*}$ & $.144^{*}$ & .139 & $.582 *$ \\
\hline $\begin{array}{l}\text { Union } \\
\text { Instrument }\end{array}$ & 3.40 & .824 & $.550^{*}$ & 1.0 & $.373^{*}$ & $.294 *$ & $.305^{*}$ \\
\hline Them \& Us & 3.18 & 1.012 & $.144 *$ & $.373^{*}$ & 1.0 & -.007 & .093 \\
\hline $\begin{array}{l}\text { Workplace } \\
\text { Collectivism }\end{array}$ & 4.02 & .589 & .139 & $.294 *$ & -.007 & 1.0 & .054 \\
\hline $\begin{array}{l}\text { Union } \\
\text { Participation }\end{array}$ & 3.17 & .844 & $.582 *$ & $.305^{*}$ & .093 & .054 & 1.0 \\
\hline
\end{tabular}

* Correlation is significant at the 0.05 level (1-tailed). 
Table: 3 Linear Regression Analysis

\begin{tabular}{|l|l|l|l|l|l|}
\hline & $\mathrm{R}^{2}$ & $\begin{array}{l}\text { Adjusted } \\
\mathrm{R}^{2}\end{array}$ & $\begin{array}{l}\text { Standard } \\
\text { Error of the } \\
\text { Estimate }\end{array}$ & F Value & $\begin{array}{l}\text { Sig. } \\
(\mathrm{p}<.05)\end{array}$ \\
\hline Union Loyalty & .338 & .334 & .82609 & 80.745 & .000 \\
\hline Union Instrumentality & .093 & .087 & .96702 & 16.160 & .000 \\
\hline Them \& Us & .009 & .002 & 1.001 & 1.380 & .241 \\
\hline Workplace Collectivism & .003 & -.003 & 1.014 & .455 & .501 \\
\hline
\end{tabular}

Dependent Variable: Union participation

The first hypothesis was in respect of identifying the positive relationship between perceived union loyalty and union participation. Correlation between union loyalty and union participation is 0.582 which is the strongest association compared to other variables. According to the table 2, $\mathrm{R}$ square is 0.338 , which implies $33.8 \%$ of the variance in union participation in trade union of the operational level employees is explained by the independent variable of union loyalty. At the same time only a small margin of error, $\mathrm{e}=.83$ is involved in the regression line. According to the results of both correlation and simple regression it was possible to substantiate the alternative hypothesis and the data support to conclude that there is a positive association between perceived union loyalty and union participation.

The second hypothesis is the association between perceived union instrumentality and union participation. Correlation coefficient is .305 at the .05 significant level indicating a moderate relationship between these two variables. Linear regression analysis shows that $\mathrm{R}$ square is .093 with standard error of estimate of .967 , which has a slighter impact on union participation. The $\mathrm{F}$ value is 16.160 , which is significant at $5 \%$ level $(\mathrm{p}=.05)$, suggesting that union instrumentality has significantly explained $9.3 \%$ of the variance of union participation.

The third hypothesis is about the positive relationship between union members perceived them and us attitude and union participation in trade union activities. The simple regression analysis indicates $\mathrm{F}$ value 1.380 , and correlation coefficient is 0.093 , both were not significant at $5 \%$ confidence level. Hence alternative hypothesis was rejected as there is no significant relationship between union members' them and us attitude and union participation.

The fourth hypothesis was about measuring the direct relationship between workplace collectivism and union participation. Correlation coefficient .054 indicates a positive correlation; however it is not significant at .05 confidence level. As indicated by table 2, R square .003, with $\mathrm{F}$ value of .455 is not significant ( $\mathrm{p}>.05$ ). Hence alternative hypothesis is not substantiated as there is no significant relationship between workplace collectivism and union participation.

The final hypothesis of the study involved in examining the aggregate effect of all the independent variables on union participation. Multiple regression analysis was conducted to test the hypothesized relationships. Table 4 and 5 show the results obtained from regressing the "union participation" measure on union loyalty, union instrumentality, them and us attitude and workplace collectivism. 
Table: 4 Model Summary with ANOVAs

\begin{tabular}{|l|l|l|l|l|l|l|}
\hline Model & $\mathrm{R}$ & R Square & $\begin{array}{l}\text { Adjusted } \\
\text { Square }\end{array}$ & $\begin{array}{l}\text { Std. Error of } \\
\text { the Estimate }\end{array}$ & Sig. \\
\hline 1 & $.583^{\mathrm{a}}$ & .340 & .319 & .83537 & 15.894 & $.000^{\mathrm{a}}$ \\
\hline
\end{tabular}

a. Predictors: (Constant), Union Loyalty, Union Instrumentality, Them and us attitude and Workplace Collectivism

b. Dependent Variable: Union Participation.

\section{Table: 5 Coefficients ${ }^{\mathbf{a}}$}

\begin{tabular}{|c|c|c|c|c|c|c|}
\hline & & \multicolumn{2}{|c|}{$\begin{array}{l}\text { Unstandardized } \\
\text { Coefficients }\end{array}$} & \multirow{2}{*}{ 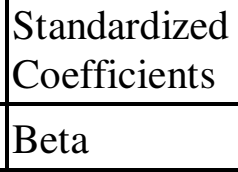 } & \multirow[b]{2}{*}{$\mathrm{t}$} & \multirow[b]{2}{*}{ Sig. } \\
\hline \multicolumn{2}{|c|}{ Model } & B & Std. Error & & & \\
\hline 1 & (Constant) & 1.505 & .569 & & 2.646 & .009 \\
\hline & Union Loyalty & .639 & .090 & .612 & 7.086 & .000 \\
\hline & Union Instrumentality & -.020 & .108 & -.016 & -.184 & .854 \\
\hline & Them Us & .019 & .105 & .013 & .178 & .859 \\
\hline & $\begin{array}{l}\text { Workplace } \\
\text { Collectivism }\end{array}$ & -.035 & .119 & -.020 & -.294 & .769 \\
\hline
\end{tabular}

a. Dependent Variable: Union Participation

According to the Table 4 overall model accounted for $34 \%$ of the variance in union participation which highlights the relevance of these variables in attempting to explain the members' involvement in trade union activities. Hence final hypothesis of the study is substantiated. However, as per the table 5, union loyalty emerged as the only significant predictor of union participation. It shows that union instrumentality, them and us attitude and workplace collectivism are not significant predictors of union participation, thought they have the ability of affecting union participation jointly.

\section{Conclusion}

The main objective of the study was to identify the impact of union loyalty, union instrumentality, them and us attitude and workplace collectivism on union participation in relation to operational level employees in public sector organizations in Sri Lanka. The study found empirical evidence to support that union loyalty and union instrumentality have positive significance impact on union participation of trade union members. However, "them and us" attitude and workplace collectivism do not have significant impact on union participation. In his study Metochi (2002) explained that union loyalty, collectivist orientation and service oriented leadership emerged as significant predictors of willingness to participate and accounted for 21 percent of the variance explained. Further, union loyalty is the most powerful predictor of willingness to participate in trade union activities; whereas, them and us attitude is not a significant predictor which is consistent with this study. Union loyalty emerged as the most significant predictor and accounted for 33 percent of the variance explained. The strong 
significant effect of union loyalty indicates the importance of affective attachment to the union which results in union participation. These results are indirectly related to studies of Tetrick et al, (2007); Barling et al (1991); Bolton et al, (2007).

The traditional role of the union in establishing conditions of employment that protects member rights for safe working conditions and fair treatment, as reflected in instrumentality, is a primary purpose of unions (Cregan, 2005). Shore and Tetrick's (1994) argue that fulfillment of employment goals is a critical element for the development and maintenance of the exchange relationship between the individual and the organization. That is, instrumentality may signify the degree to which the member's goals for membership are in fact fulfilled, leading to perceived union instrumentality to become a determinant of union participation in trade union activities. This study becomes consistent with these theories, showing that union instrumentality is positively and significantly related to union participation, however it is not a strong predictor at the aggregate results of final model of union participation.

The findings of the study done by Cregan (2009) demonstrate that social identification with fellow members at the workplace is associated with collectivism in the individual worker; therefore, unions are encouraged to foster the development of the workplace union. Social identification, however, needs a critical mass of members. Metochi (2002) identifies that members' collectivist orientation suggests that the more favourable members' attitude towards collective forms of representation and action is in achieving desired outcomes and protecting their interest, the more willingness they will have to participate in union activities. This study shows results contrasted to these findings as workplace collectivism is not a significant predictor of union participation of operational level employees in public sector organizations in Sri Lanka. The identification with work group/ departmental and a perception of shared values and interest did not influence member participation in the union when members are involved in diverse occupational categories. In this study union members are in operational level, however they belong to wider occupational categories, e.g. technical staff, supportive staff, and clerical staff etc. Hence the perception of shared interest with the wider groupings would be weaker. The perceived ability of the union to achieve certain outcomes becomes more relevant, as union members are more concerned with the costs and benefits of participation.

This study was limited to four factors of union participation of the operational level employees in the public sector organizations. Future studies can be done regarding union participation of nonoperational employees and employees in the private section in the country. Also some possible variables such as union leadership, pro-union attitudes and perceived union support can be used as factors which may determine the degree of union membership participation significantly.

\section{REFERENCES}

Amerasinghe, E.F. G. (2011), Employee Relations in Sri Lanka, Cornucopia.

Aryee S., and Debrah, Y.A. (1997), Members' Participation in the Union: An Investigation of Some Determinants in Singapore, Human Relations, Vol. 50, No. 2, pp. 129-147.

Bamberger, P. A., Kluger, A. N., and Suchard, R. (1999), The antecedents and consequences of union commitment: A meta-analysis, Academy of Management Journal, 42, pp. 304 318. 
Barling, J., Kelloway, E. K., and Bremermann, E. H. (1991), Pre-employment predictors of union attitudes: The role of family socialization and work beliefs, Journal of Applied Psychology, Vol. 76, No. 5, pp. 725-731.

Bender, K. A., and Sloane, P. J. (1998), Job satisfaction, Trade unions and Exit voice revisited Industrial and Labour Relations, Review, Vol. 51, No. 2, Cornell University.

Bolton, D., Bagraim J.J., Witten, L., Mohamed Y., Zvobgo, V., and Khan M. (2007), Explaining Union Participation: The effect of union commitment and demographic factors, Journal of Industrial Psychology, Vol. 33, No. 1, pp. 74-79.

Brown, R., Condor, S., Mathews, A., Wade, G. and William, J. (1986), Explaining intergroup differentiation in an industrial organization, Journal of Occupational Psychology, 59, pp. 273-86.

Cohen, A. (1994), An empirical assessment of the multidimensionality of union participation, Journal of Management, 19, pp. 749 -773.

Cregan, C., Bartram, T. and Stanton, P. (2009), Union Organizing as a Mobilizing Strategy: The Impact of Social Identity and Transformational Leadership on the Collectivism of Union Members, British Journal of Industrial Relation, Vol. 47, No. 4, pp. 701-722.

Deshpande, S.P. and Fiorito, J. (1989), Specific and general beliefs in union voting models. Academy of Management Journal, 32, pp. 883-897.

Fullagar, C. (1986), A factor analytic study on the validity of a union commitment scale, Journal of Applied Psychology, 71, pp. 129-136.

Fullagar, C., and Barling, J. (1989), A longitudinal test of a model of the antecedents and consequences of union loyalty, Journal of Applied Psychology, 74, pp. 213-227.

Fullagar, C., Clark, P.F., Gallagher, D.G., and Gordon, M. E. (1994), A model of the antecedents of early union commitment: the role of socialization experiences and steward characteristics, The Journal of Organizational Behavior, 15, pp. 517 - 533.

Fullagar, C., Gallagher, D.G., Gordon, M.E., and Clark, P.F. (1995), Socialization on union commitment and participation: A longitudinal study. Journal of Applied Psychology, 89, pp. 147-157.

Gordon, M.E., Philpot, J.W., Burt, R.E., Thompson, C.A., and Spiller, W.E. (1980), Commitment to the union: Development of a measure and an examination of its correlates, Journal of Applied Psychology, 65, pp. 479-499.

Hammer, T. H., Bayazit, M., and Wazeter, D. L. (2009), Union leadership and member attitudes: a multi-level analysis, The Journal of Applied Psychology, Vol. 94, No. 2, pp. 392-410.

Hair, J.F., Anderson, R.E., Tatham, R.L., and Black, W.C. (1998), Multivariate data analysis (6th ed), Upper Saddle River, NJ: Prentice Hall.

Jinadasa, P.C.V. and Opatha H.H.D.N.P. (1999), An empirical study of membership participation in trade union activities: Evidence from selected Service Organizations in Sri Lanka, Sabaragamuwa University Journal, Vol. 2, No. 1, pp. 17-3.

Kelloway, E. K., and Barling, J. (1993), Members' participation in local union activities: Measurement, prediction and replication, Journal of Applied Psychology, 78, pp. 262279.

Kuruvilla, S., Gallagher D., G., Fiorito, J., and Wakabayashi M. (1990), Union participation in Japan: Do Western Theories Apply? Industrial Relations Review, Vol. 43, No. 4, pp. 374-390. 
Kelloway, E. K., Catano, V. M. and Southwell, R. R. (1992), 'The construct validity of union commitment; development and dimension of a shorter scale', Journal of Occupational and Organizational Psychology, 65.

Kelly, C. and Kelly, J. (1994), 'Who gets involved in collective action? Social psychological determinants of individual participation in trade unions', Human Relations, 47, pp. 6388.

Kelly, J. (1998), Rethinking Industrial Relations: Mobilisation, Collectivism and Long Waves. London: Routledge.

McShane, S. (1986), The multidimensionality of union participation, Journal of Occupational Psychology, 59, pp. 177-187.

Monnot, M.J., Wagner, S. and Beehr, T.A. (2011), A contingency model of union commitment and participation: Meta-analysis of the antecedents of militant and nonmilitant activities, Journal of Organizational Behaviour, John Wiley \& Sons, Ltd. do:10.1002/job.736

Morrow P.C. and McElroy, J.C. (2006), Union Loyalty Antecedents: A Justice Perspective, Journal of Labour Research, XXVIL (1), pp. 31-52.

Metochi, M. (2002), The influence of leadership and member attitudes in understanding the nature of union participation, British Journal of Industrial Relations, Vol. 40, No. 1, pp. 87-111.

Nicholson, N., Urse U. G. and Blyton, P. (1981), The Dynamics of White Collar Unionism: A Study of Local Union Participation, London: Academic Press.

Newton, L. A., and Shore, L. M. (1992), A model of union membership: Instrumentality, commitment, and opposition, Academy of Management Review, 17, pp. 275-298.

Sekaran U. (2006), Research Methods for Business, (4 ${ }^{\text {th }}$ ed.), New York: John Wiley's \& Sons, Inc.

Sinclair, R. R. and Tetrick, L. E. (1995), Social exchange and union commitment: A comparison of union instrumentality and union support, Journal of applied psychology, 79, pp. 971977.

Shore, L. M., and Newton, L. A. (1995), Union-member relations: Loyalty, instrumentality, and alienation, In L. E. Tetrick and J. Barling, Changing Employment Relations: Behavioral and Social Perspectives (189 -208), Washington, DC: American Psychological Association.

Shore, L. M., Tetrick, L. E., Sinclair, R. R., and Newton, L. A. (1994), Validation of a measure of perceived union support, Journal of Applied Psychology, 79, pp. 971-977.

Tetrick, E.L., Shore L. M., McClurg, L.N., and Vandenberg R. J. (2007), A Model of Union Participation: The Impact of Perceived Union Support, Union Instrumentality, and Union Loyalty, Journal of Applied Psychology, Vol. 92, No. 3, pp. 820 - 828. 